\title{
Acquired Cataract
}

National Cancer Institute

\section{Source}

National Cancer Institute. Acquired Cataract. NCI Thesaurus. Code C98802.

Cataract that results from the aging process, an injury, or as a manifestation of a systemic disorder. 